\title{
CONCEPTUAL FRAMEWORK OF THE DEVELOPMENT OF PROSPECTIVE SKILLED MACHINE-BUILDING INDUSTRY EMPLOYEES' SELF-EDUCATION COMPETENCE
}

\author{
Serhii Osypenko \\ Postgraduate student at the Institute of Vocational Education and Training of NAES of Ukraine \\ http://orcid.org/0000-0002-6575-2321 \\ e-mail: osipenko.sergey26@gmail.com
}

\begin{abstract}
The conceptual provisions of the purposeful development of the prospective skilled employees' self-education competence in the Institutions of Vocational Education (Vocational Education and Training) (hereinafter referred to as IVE (VET)) are investigated. It is determined that at present the level of educational process organization in IVE (VET) doesn't meet the requirements of modern production. Among the main vectors for the modernization of vocational training of prospective skilled employees, the dominant of which should be made on the development of students' self-educational abilities, and technological knowledge of the machine-building industry skilled employees must be constantly improved and replenished with new information.

The results of the definitive analysis of such significant for the research concepts as "competence approach", "competence", "qualification" are manifested.

Self-education competence is interpreted as a personality's integrated property synthesizing knowledge, skills, experience of self-education and personal qualities that can be performed in productive student's selfeducation activity and behavior and ensure a prospective skilled worker's preparedness and ability to identify deliberately the reality, to master reasonably the social experience of mankind and perform self-realization.

It is defined that self-education competence of a prospective machine-building industry skilled employee is constructed of five interdependent and mutually determined components: motivational-valuable, cognitive, operational-activity-oriented, organizational-volitional and reflexive-evaluative.

The principal methodological approaches (competence, personality-oriented, activity-oriented, systematic, reflexive, axiological, informational, environmental) and pedagogical principles of the development of prospective skilled employees' self-education competence (value-substantive orientation, system and consistency, continuity, personification, mobility, researching, reflection, visibility, humanization, problem solving, integration) are suggested.

On the basis of factor analysis, pedagogical conditions are determined, the directions for achieving the goal of purposeful development of students' self-education competence in IVE(VET) of machine-building profile are given.

The prospect of further scientific research, related to the design of methods and technologies for the development of students' self-educational competence in the Institutions of VE (VET) of machine-building profile, are defined.
\end{abstract}

Keywords: competence approach, self-education competence, prospective machine-building industry employees, educational process, methodological approaches.

Introduction. The socioeconomic challenges of the present suggest the substantial renovation of the skilled workers' vocational training: the level of the educational process organization in the Institutions of Vocational Education (Vocational Education and
Training) (hereinafter referred to as IVE (VET)) does not meet the requirements of modern production. This is the consequence of the lack of sufficient logistics of the IVE (VET), outdated qualification characteristics, which are extremely slowly replaced by modern 
professional standards, insufficient level of pedagogical skills of teachers and vocational training instructors, decline of labour occupations prestige. Instead, the scientific and technological progress proves to be the most important transformational factor. Innovative development in technology, equipment, information confirm it's impossible to provide a student with a certain amount of knowledge and skills for the whole life. The required technological knowledge of the machine-building industry specialist must be constantly improved, updated with new information on the implementation of labor operations and activities ? otherwise he becomes functionally incapacitated.

Naturally, it is impossible to predict such changes in the content of training the prospective turners, millers, locksmiths, electric welders, even on the principles of cutting-edge vocational training. Therefore there is an urgent need to form students' selfeducational abilities, abilities and skills of independent development of their intellectual and creative potential. Taking these positions into account, the problem of students' self-education competence development in IVE (VET) is a pertinent scientific task.

Materials and methods. Scientific and pedagogical aspects of students' vocational selfeducation, self-development, independent work remain relevant and controversial at all stages of the pedagogical science development. These issues have been investigated by A. Eisenberg, A. Avdeyev, L. Aristova, A. Asherov, S. Goncharenko, N. Zhuravskaya, S. Zaskalet, O. Kovalenko, G. Kodzhespirova, V. Kozakov, N. Kuzmina, M. Lerner, N. Nichkalo, V. Radkevich, G. Serikov, M. Skatkin, M. Fitsula. The fundamentals for forming selfeducation competence of those who are studying is considered in the куыуфсруы of V. Buryak, N. Bukhlova, B. Vovk, M. Kuzmina, N. Kubrakova, S. Melnyk, I. Mosi, P. Osipovov, N. Polovnikova, V. Sknar and others.

It has been determined that the self-educational competence of a student is an integrative property of a person that structurally and functionally ensures effective masterying of future vocational activity and is the factor that provides the social competitiveness of a graduate of a vocational educational institution. However, the results of the analysis of psychopedagogical literature confirm the conceptual and theoretical aspects of the development of the prospective skilled machine-building industry' selfeducational competence are considered to be insufficiently substantiated, and this impedes the development and application of productive technologies and techniques for students' selfeducation activities under the conditions of IVE (VET).

Research methods. Theoretical: theoretical analysis, normative documents study, analysis of educational process in order to determine the state of the problem's development and to define the directions of scientific research; comparison in order to investigate various scientific approaches to problem study; analysis and synthesis for substantiation of methodological approaches and the principles of development of students' self-educational competence; empirical: observation, conversation, questionnaire in order to determine the factors, pedagogical conditions, stages of development of students' self-educational competence; peer reviewing for assessing the importance of certain factors for the development of students' self-educational competence.

The aim of the paper is to determine the conceptual provisions for the purposeful development of the prospective skilled machine-building industry employees' self-educational competence in the IVE (VET).

Results and discussions. The conventional model of the educational process in IVE (VET) (primarily to provide students with programmed amount of knowledge, and then to involve them in the application of the theory into practice) has not really been sufficiently renovated according to the logic of the competence approach providing the prospective skilled specialists' with comprehensive mastery of integrative knowledge and practical skills, personal competency system, which facilitates the successful functioning of a person in main spheres of human life. In this regard, the improvement of the vocational training of the prospective skilled specialists, taking into account the provisions of the competence approach, is one of the most significant tasks of the national vocational education at all levels.

The analysis of available psycho-pedagogical and philosophical researches confirms a solid experience of scholars in the field of the skilled employees' competence-oriented training in IVE (VET). In the national scientific and pedagogical environment, scientists and practitioners developed a consensus on the essence of the main terms of the competence paradigm in education: competence is a dynamic combination of knowledge, skills, ways of thinking, views, values, other personal qualities, which determines the ability of a person to socialize successfully, conduct professional and / or further educational activities (Law of Ukraine "On Education", 2017); competency approach is a new paradigm that directs education to develop a whole set of competences (knowledge, skills, attitudes, etc.) that the prospective specialists have to master (Khiminets, 2009); a method of modeling the results of vocational education and training and their representation in the form of quality standards for the skilled workers' training. The peculiarity of the competency approach in vocational education and training is its humanistic, 
humanitarian and practical orientation for ensuring professional development and self-affirmation of the individual (Radkevich, 2012); orientation on the development of the system complex of skills, semantic orientations, adaptation opportunities, experience and methods of transformation activity to obtain a specific product (Nagach, 2008); shifting the emphasis from the process of accumulation of normatively defined knowledge, skills and abilities of the prospective specialists into the area of formation and development of the ability to implement in practice and apply creatively the acquired knowledge and experience in different situations (Rudnitskaya, 2016). Qualification is recognized by the qualification center as the subject of educational activity, another authorized entity, and a standardized set of competencies (results of training) acquired by the person certified with the corresponding document, which allow to perform a certain type of work or perform professional activities (Pukhovskaya et al., 2014).

Agreeing with the opinions of scholars (Kalensky and others, 2018; Rudnitskaya, 2012) regarding the essence of the professional competence of the prospective skilled employees, we determine this phenomenon as an integrative property of the individual, which is manifested in practice, behavior and actions of the individual and stipulates his readiness to perfom functions of a skilled worker by virtue of of a balanced combination of a complex of knowledge, abilities, needs and motives of selfimprovement, moral and ethical values and necessary personal and professional qualities.

In the study, the self-educational competence is defined as an integrated personality property that synthesizes knowledge, skills, self-education experience and personal qualities that are manifested in productive self-education and student behavior and ensure the readiness and ability of a prospective skilled employees to identify deliberately the reality motivating to master the social experience of mankind and self-realization.

In this interpretation, the self-educational competence, on the one hand, is a criterion for the preparation of an IVE (VET) graduate to professional activity, an indicator of the quality of his vocational training, and therefore, in our opinion, can support the system of generic-specific relationships with the professional competence of a person. From such perspective, the formation of a graduate's selfeducation competence ensures his professional mobility - the ability not only to continue improving independently his professional knowledge and skills, but also the intention to improve systematically the qualifications, if necessary, to change the specialty. On the other hand, self-education competence is firmly attributed to a group of key (subjective, interdisciplinary) competencies that are at its top in the "pyramid of competencies"and provide a successful development of the pertinent ability of a person to operate effectively in a social environment. In this sense, the self-education competence of the graduate of the IVE (VET) determines the academic mobility of the prospective skilled worker, his ability to master the educational-professional program, and so on.

In our scientific research it is determined that the self-educational competence of the prospective machine-building industry skilled employee is the construct of such interdependent and mutually determined components: motivational-valuable (involves the formation of persistent needs, positive motives, aspiration for constant self-education, awareness of the personal and social significance of self-education); cognitive (characterizes the amount of knowledge about the techniques of self-education, its form, content, receptions, levels of possession of general, objective and professional knowledge and skills, the skills of applying modern IT technologies in self-education); operational-activity (performing an instrumental function, this component represents an interconnected set of skills and abilities, the ability to choose the appropriate types and methods of teaching that facilitate effective self-education activities implementation); organizational-volitional (characterizes persistence, purposefulness, student's confidence in successful self-development, selfimprovement, involves the formation of the skills of optimal organization of their own self-education activities, skills of rational organization of the workplace); reflexive-evaluative (involves student's analysis and self-evaluation of his achievements, the ability to reflect in self-education, the possession of reflexive technologies in self-education).

The content of the determined components of the prospective machine-building industry skilled employee's self-educational competence is concordant with the position of V.Buryak concerning the structure of person's preparedness for self-education, the main elements of which the scientist equitably allocates to such groups (Buryak, 2005): a holistic emotional and personal apparatus (need for self-improvement, personal values, emotional-volitional framework, general mental abilities, etc.); a system of knowledge and skills, skills of self-education, assimilated by a personality (completeness and depth of scientific concepts, interrelations between them, ability to correlate scientific concepts with objective reality, etc.); skills and abilities to work competently with the main sources of social information, books in particular, bibliographic systems, automated information searching tools, ability to navigate in large volumes of information, choose the main material, record it, etc.; system of organizational and managerial skills and 
abilities (to set and fulfill the tasks of self-education, plan the work, skillfully distribute time, provide favorable conditions for activity, perform self-control, self-analysis of results, etc. ).

Taking into account that the self-education competence of the prospective machine-building industry skilled employee is a dynamic capability of a person, we distinguish four levels in the process of its development: low; average; sufficient; high.

The methodology of developing the prospective skilled employees' self-education competence is determined by the unity of such fundamental scientific approaches: competence (reflects the content of selfeducation, which is not limited to a knowledge-oriented component, but involves the acquisition of a holistic experience of solving problems arising in socioprofessional situations); personally oriented (involves students' interests, motives, guidelines, values, the unity of intellectual, cultural, spiritual development of the individual and is implemented through the strengthening of the content of self-education humanscience, personally significant material); activity approach (directing practice, grounded on the development of self-educational competence, to forming the motivation of the prospective skilled employees, learning how to understand the educational problems, determining the ways of their solving, the ability to perform self-education by means of direct involvement of students in self-education activity); systemic (enabling the development of self-education competence as a complex personality formation in the context of improving the structure of the self-education process (the purpose of self-education, methods, forms, means, self-education content, self-control of results, etc.); reflexive (development of reflexive knowledge, students' reflexive thinking, reflexive attitude, reflexive skills and methodological reflection for the purpose of self-examination and self-control of own selfeducation activity); axiological (directing the selfeducational process onto the obtaining the system of universal, national, civic, family, personal and other values by prospective machine-building industry skilled employee that determine the IVE (VET) students' attitude to the world, to people, to oneself); informational (involving the rational use of educational and cognitive potential of informational activity, using IT technologies in particular, in the aspect of search, accumulation, analytical and synthetic processing, storage and distribution of educational information); environmental (provides the opportunity to recognize the informational and educational environment as the main factor in attracting students to self-education, as a complex of pedagogical incentives for selfeducation).

The mentioned methodology for the development of the prospective skilled employees' self-education competence is being implemented under the following principles: value-content orientation, system and sustainability, continuity, personification, mobility, scientific development, reflection, visibility, humanization, problem solving, integration.

It's reasonable that the compliance with these principles requires establishing the appropriate conditions for the development of the students' selfeducational competence, determined by means of factor analysis. The results of our experimental study suggest the main psychological and pedagogical factors of the investigated process: establishing students' need for self-education; capacities of modern IT technologies and the Internet; organization of educational process (share of independent work in the structure of study time); innovative learning technologies (design, problem-developing, training, simulation games, etc.); the complexity of the modern content of education; Information and educational environment of IVE(VET); educational activities of the teacher, instructor of industrial training; the system of control of students' achievements in IVE(VET); students' cognitive abilities; requirements of production (practice) for the qualification of machinebuilding industry skilled employee; organization of intellectual extra-curricular activities of students (contests, circles, clubs, studios, etc.).

Pedagogical conditions are defined on the basis of the inductive method of establishing cause-and-effect relations and these conditions being provided can transform experimentally determined factors into real determinants of the development of students' selfeducation abilities, giving them the qualities of effectuality. The suggested pedagogical conditions are: permanent formation of students' needs for selfeducation; productive organization of independent work of the prospective skilled employees; implementation of interactive learning technologies into the process of skilled workers' vocational training; purposeful development of informational and analytical culture of the pedagogical interaction participants.

At the same time, it should be noted that the driving forces for the development of the prospective machinebuilding industry skilled employees' self-education competence are not single factors or conditions, but the contradictions arising in the real educational process. Acquaintance with the results of academic researches of scholars, pedagogical experience of practical development of students' self-educational abilities made it possible to identify a number of contradictions existing in vocational (vocational and training) education, particularly between:

- the needs of the machine-building industry for workers with a high level of vocational competence and the low preparedness of graduates of IVE (VET) for self-education; 
- requirements of the National Qualification Framework, the Law of Ukraine "On Education", qualification standards for key competencies of skilled workers, and insufficient development of theoretical and methodological foundations for the purposeful development of self-educational abilities of students of the IVE (VET) in the machine-building educational profile;

- the latest tasks of the IVE (VET) concerning the training of competitive, professionally mobile workers in the machine-building industry - and the low preparedness of teachers, instructors of industrial training to provide pedagogical support to the processes of developing students' self-education activities;

- the necessity to train the vocationally competent skilled workers with established preparedness for self education ? and the lack of educational and methodical and didactic materials providing students' selfeducation in IVE (VET) in the machine-building educational profile.

According to the results of the pilot experimental study, we define the following directions of the revealed contradictions solution:

- substantiation and implementation of interactive learning technologies (technology teaching projects, case study, technology of distance learning, etc.) into the educational process which, structurally and functionally, requires the student's independent work;

- extensive implementation of the system of teaching methods comprising reproductive, algorithmic methods of teaching systematically replaced by productive, research methods of mastering professional knowledge, and modern innovative teaching methods (IT technologies) in pedagogical practice;

- interdisciplinary, methodological character of the training of prospective machine-building industry skilled employees with an orientation towards creative development of the individual;

- overall informatization of vocational education, designing and establishing of informational and educational environment in IVE (VET) of the machinebuilding profile;

- selection and structuring of the content of education of prospective machine-building industry skilled employees on advanced training principles;

- objectivity of methods of evaluation (and selfevaluation) of students' learning achievements, in particular in conditions of distance learning or mixed learning;

- pedagogical support of the processes of students self-education and self-development.

We should state that the implementing of the abovementioned directions of contradictions resolving, and the achieving the goal of purposeful development of students' self-educational abilities must be performed within three consecutive stages: diagnostic and motivational (to determine the state of applicants' for the machine-building industry skilled employee training programme the ability of self-education activities, to form the students perceptions of their intellectual ability, to form an aspiration for selfimprovement, an interest in independent obtaining vocational and other knowledge, ability to selfeducational activity planning, to organize comfortable workplace for learning, to inspire students to make personal start "portfolio" and program of selfeducation, etc.); activity-technological (provision of organizational and pedagogical conditions for gradual advancement of students from episodic self-education, as a result of pedagogical incentives, to sustainable self-education activities under the influence of motivesinterests, implementation of self-education programme by students on their own self-educating trajectory at a comfortable rhythm of self-education classes; reflexive-corrective (maintaining skills of selfeducation and self-development, improvement of students' ability to analyze, evaluate, correct the results of self-education using methods of self-influence self-controlling, self-reporting, self-persuasion, selfprogramming, self-examining, self-correcting, complacency, etc.).

Conclusions. Summing up, in our study we investigated and determined the provisions of purposeful development of the prospective skilled employees' self-education competence in IVE (VET) based on the substantiated directions and stages of solving the problem as an attempt to elaborate methodological and theoretical concepts of this integrative individual property development.

Prospects for further scientific research are related to the design of methods and technologies for the development of the students' self-educational competence in IVE (VET) of machine-building educational profile.

\section{List of references}

Буряк В.А., 2005. Розвиток професійно-педагогічних якостей у системі безперервної освіти. Вища школа, 2 , с. 50-57.

Верховна Рада України. Законодавство України, 2011 а. Закон України "Про освіту" від 05.09.2017 p. № 2145 VIII. [online] (Останнє оновлення 28 Вересень 2017) Доступно: <http://zakon3.rada.gov.ua/laws/show/2145-19> [Дата звернення 9 Травень 2018]. 
Верховна Рада України. Законодавство України, 2011 b. Національна рамка кваліфікацій. Додаток до постанови Кабінету Міністрів України від 23 листопада 2011 р. № 1341. [online] (Останнє оновлення 06 Січень 2012) Доступно: <http://zakon4.rada.gov.ua/laws/ show/1341-2011-\%D0\%BF>. [Дата звернення 9 Травень 2018].

Каленський, А. А., Лузан, П. Г., Ваніна, Н. В. та Пащенко Т. М., 2018. Стандартизація професійної освіти: теорія і практика; монографія. Житомир: "Полісся".

Нагач, М.В., 2008. Підготовка майбутніх учителів у школах професійного розвитку в США: автореферат. Кандидат наук. Університет менеджменту освіти Академії педагогічних наук України.

Пуховська, Л. П., Варначев А. О., Мельник С. В. та Кравець Ю. І., 2014. Професійні стандарти і кваліфікації у краӥнах з високо розвинутою економікою. К.: "НВП Поліграф сервіс".

Радкевич, В.О., 2012. Компетентнісний підхід до забезпечення якості професійної освіти і навчання. В: Науково-методичне забезпечення професійної освіти і навчання: звітна науково-практична конференція. Київ: Інститут професійно-технічної освіти НАПН України, с. 5-12.

Рудніцька, К. В., 2016. Сутність понять "компетентнісний підхід", компететентність", "компетенція", "професійна компетентність" у світлі сучасної освітньої парадигми. Науковий вісник Ужгородського університету. Серія "Педагогіка. Соціальна робота", 1(38), с. 241-244.

Химинець, В.В., 2009. Інноваційна освітня діяльність; монографія. Тернопіль: Мандрівець.

\section{Translated \&Transliterated}

Buriak V.A., 2005. Rozvytok profesiino-pedahohichnykh yakostei u systemi bezperervnoi osvity [Development of professional and pedagogical qualities in the system of continuous education]. Vyshcha shkola [Higher School], 2, s. 5057, [in Ukrainian].

Verkhovna Rada Ukrainy. Zakonodavstvo Ukrainy [Verkhovna Rada of Ukraine. Legislation of Ukraine], 2011 a. Zakon Ukrainy "Pro osvitu" [Law of Ukraine "On Education"] dated 05.09.2017 r. № 2145-VIII. [online] (Ostannie onovlennia 28 Veresen 2017) Dostupno: <http://zakon3.rada.gov.ua/laws/show/2145-19> [Data zvernennia 9 Traven 2018], [in Ukrainian].

Verkhovna Rada Ukrainy. Zakonodavstvo Ukrainy [Verkhovna Rada of Ukraine. Legislation of Ukraine], 2011 b. Natsionalna ramka kvalifikatsii. Dodatok do postanovy Kabinetu Ministriv Ukrainy vid 23 lystopada 2011 r. № 1341 [National Qualifications Framework. Annex to the Decree of the Cabinet of Ministers of Ukraine dated November 23, 2011]. [online] (Ostannie onovlennia 06 Sichen 2012) Dostupno: $<$ http://zakon4.rada.gov.ua/laws/ show/1341-2011$\% \mathrm{D} 0 \% \mathrm{BF}>$, [in Ukrainian].

Kalenskyi, A. A., Luzan, P. H., Vanina, N. V. ta Pashchenko T. M., 2018. Standartyzatsiia profesiinoi osvity: teoriia i praktyka: monohrafiia [Standardization of Vocational Education: Theory and Practice: monograh]. Zhytomyr: "Polissia", [in Ukrainian].

Nahach, M.V., 2008. Pidhotovka maibutnikh uchyteliv u shkolakh profesiinoho rozvytku v SShA: avtoreferat [Preparation of future teachers in professional development schools in the USA: abstract. PhD. University of Management Education of the Academy of Pedagogical Sciences of Ukraine.]. Kandydat nauk. Universytet menedzhmentu osvity Akademii pedahohichnykh nauk Ukrainy, [in Ukrainian].

Pukhovska, L. P., Varnachev A. O., Melnyk S. V. ta Kravets Yu. I., 2014. Profesiini standarty i kvalifikatsii u krainakh $z$ vysoko rozvynutoiu ekonomikoiu [Professional standards and qualifications in highly developed economies]. K.: "NVP Polihraf servis", [in Ukrainian].

Radkevych, V. O., 2012. Kompetentnisnyi pidkhid do zabezpechennia yakosti profesiinoi osvity i navchannia [Competency approach to ensuring the quality of vocational education and training]. V: Naukovo-metodychne zabezpechennia profesiinoi osvity i navchannia: zvitna naukovo-praktychna konferentsiia [Scientific and methodological provision of vocational education and training: scientific and practical conference]. Kyiv: Instytut profesiino-tekhnichnoi osvity NAPN Ukrainy, s. 5-12, [in Ukrainian].

Rudnitska, K. V., 2016. Sutnist poniat "kompetentnisnyi pidkhid", kompetetentnist", "kompetentsiia", "profesiina kompetentnist" u svitli suchasnoi osvitnoi paradyhmy [The essence of the concepts of "competence approach", competency", "competence", "professional competence" in the context of the modern educational paradigm]. Naukovyi visnyk Uzhhorodskoho universytetu. Seriia "Pedahohika. Sotsialna robota" [Academic Journal of Uzhgorod University. Series "Pedagogy. Social work], 1(38), s. 241-244, [in Ukrainian].

Khymynets, V.V., 2009. Innovatsiina osvitnia diialnist: monohrafiia [Innovative educational activities; monograph.]. Ternopil: Mandrivets, [in Ukrainian]. 


\section{Концептуальні основи розвитку самоосвітньої компетентності майбутніх кваліфікованих робітників машинобудівної галузі}

\section{Сергій Осипенко,}

аспірант Інституту професійно-технічної освіти НАПН України

Реферат. Висвітлено концептуальні положення цілеспрямованого розвитку самоосвітньої компетентності майбутніх кваліфікованих робітників машинобудівної галузі в закладах професійної (професійно-технічної) освіти (далі ЗП(ПТ)О). Наголошено, що наразі рівень організації освітнього процесу в ЗП(ПТ)О вже не відповідає вимогам сучасного виробництва. Серед основних векторів модернізації професійної підготовки майбутніх кваліфікованих робітників домінанта має зміститися на розвиток самоосвітніх здатностей учнів, а технологічні знання робітника машинобудівної галузі мають постійно змінюватися, поповнюватися новою інформацією.

Наведено результати дефінітивного аналізу найважливіших для проблеми дослідження понять: "компетентнісний підхід", "компететність", "кваліфікація". Самоосвітню компетентність витлумачено як інтегровану властивість особистості, що синтезує знання, уміння, навички, досвід самоосвіти та особистісні якості, котрі виявляються у продуктивній самоосвітній діяльності і поведінці учня та забезпечують готовність і здатність майбутнього кваліфікованого робітника цілеспрямовано пізнавати дійсність, вмотивовано освоювати соціальний досвід людства й самореалізовуватися. Визначено, що самоосвітня компетентність майбутнього робітника машинобудівної галузі $\epsilon$ конструктом п’яти взаємозалежних і взаємозумовлених компонентів: мотиваційно-ціннісного, когнітивного, операційно-діяльнісного, організаційно-вольового та рефлексивно-оцінного.

Виокремлено основні методологічні підходи (компетентнісний, особистісно-орієнтований, діяльнісний, системний, рефлексивний, аксіологічний, інформаційний, середовищний) та педагогічні принципи (ціннісно-змістової спрямованості, системності й послідовності, безперервності, персоніфікації, мобільності, науковості, рефлексії, наочності, гуманізації, проблемності, інтегрованості) розвитку самоосвітньої компетентності майбутніх кваліфікованих робітників машинобудівної галузі. На основі факторного аналізу сформульовано педагогічні умови, подано напрями досягнення мети цілеспрямованого розвитку самоосвітньої компетентності учнів 3П(ПТ)О) машинобудівного профілю.

Вказано на перспективи подальших наукових розвідок, пов'язаних із проектуванням методів і технологій розвитку самоосвітньої компетентності учнів у закладах П(ПТ)О машинобудівного профілю.

Ключові слова: компетентнісний підхід, самоосвітня компетентність, майбутні робітники машинобудівної галузі, освітній проиес, методологічні підходи. 